\title{
Britain goes for collaboration in Europe
}

London. Whatever reservations the rest of the population may have about political and economic union with Europe, British scientists are becoming increasingly enthusiastic about collaborating with their colleagues across the Channel. A survey of more than 900 scientists involved in research projects sponsored by the Commission of the European Communities (EC) has shown that virtually all academic institutions in Britain receive money from Brussels.

An analysis of participation in the commission's framework programmes shows that Britain has the largest number of links of any of the 12 member-states of the European Communities and is the most frequent partner for seven of the 11 other states including both France and Germany. In addition, four-fifths of those in the academic community receiving funds from Brussels say that it is making a significant or critical contribution to their research.

The survey was commissioned by Britain's Office of Science and Technology (OST) and the research directorate of the European Commission in Brussels and carried out by the Programme of Policy Research in Engineering, Science and Technology (PREST) at the University of Manchester and the Science Policy Research Unit (SPRU) at the University of Sussex.

The survey found that, overall, British universities receive about 5 per cent of their research funding through European programmes. The impact of this money is magnified, for example, by the fact that the Higher Education Funding Council gives extra funds to university departments that obtain research grants from Brussels.

"Our general conclusion is that, as a result of this funding, there has been a reorientation of the scientific community in this country to a point where British researchers now regard themselves as part of an emergent European scientific community", says Luke Georghiou of PREST, the leader of the research team.

The survey shows that 28 per cent of the projects funded from Brussels involve basic research; 42 per cent of the academic scientists replying said that the projects have generated unanticipated spin-offs, and 84 per cent said that the benefits of the products outweigh the costs.

The survey confirmed widespread dissatisfaction with various aspects of EC funding, in particular the time and cost involved in making grant applications to Brussels. "It was clear that the aggregate cost of all those making applications was a significant drag on the benefits to those who were cventually successful", says Georghiou.

It also revealed what many had suspected: that EC funding, like most other areas of research funding, is concentrated in the more affluent areas of the country. Apart from pockets of activity around cities such as Manchester and Edinburgh, by far the largest proportion of grants goes to southeast England.

One unexpected finding is that only 14 per cent of grant recipients describe their project as strategic research, a description that corresponds to what Brussels, nearly a decade ago, began to call "precompetitive" research. The term connotes research on which industrial competitors are supposed to collaborate to produce a common body of knowledge and to protect such joint ventures from the antimonopoly rules of the Treaty of Rome.

In contrast, more than half of the Brussels-funded projects fit the description of applied research or development. "Our overall impression is that there is probably more of a downstream focus than one would have imagined", says Gorghiou.

Another finding casting doubt on the idea of precompetitive research is that only 25 per cent of industrial groups involved in such research were collaborating with direct competitors. In contrast, 39 per cent were collaborating with "indirect competitors", those producing similar goods for different markets.

Some 32 per cent of those polled said that they were collaborating with customers and 19 per cent cited suppliers, confirming the impression that the projects have created a degree of vertical integration in the industries covered. But the most popular motive for collaboration was to gain access to complementary expertise. About 30 per cent of participants said that they intended to collaborate with other research groups on commercial applications.

Although the general attitude of industrial participants to their involvement in EC programmes was positive, it was less enthusiastic than that of academics; only 67 per cent said that the benefits outweighed the costs. Even more significantly, the survey found that only 40 per cent of the 100 companies in Britain that spend the most on research and development were participating on EC-funded projects.

Robert Jackson, parliamentary undersecretary at the OST, said that he was "disappointed" by that result. He has suggested to officials from the Department of Trade and Industry and the OST that they should investigate the reasons for such a poor record of participation. David Dickson

\section{Humboldt faculty holds its breath}

Munich. The entire academic staff of Humboldt University in East Berlin is anxiously awaiting word on who will be retained as the university becomes the last to apply criteria used in western Germany.

Western faculty are employed according to the Hochschulrahmgesetz, the general law which determines working conditions and pay at universities. Following reunification in 1989 , it was decided that academics in east German universities should be employed under the same conditions. Most universities have completed the process, but Humboldt is taking longer - right up to the 31 December 1992 deadline - because of the magnitude of the overstaffing.

At Humboldt, those retaining their jobs will receive pay raises because the new contracts employ staff at 80 per cent of the present western German wage level rather than the current level of 60 per cent. (In 1989 , the level was 15 per cent.) The general law also entitles them to greater research funding and better equipment. However, because the number of academic staff is being drastically reduced and more eastern German students are applying to university, the remaining staff will face the growing, nationwide problem of overcrowding.

This state-financed restructuring of staff at Humboldt is being carried out by a special commission set up after reunification to study the staffing needs of the university. It is redefining some jobs and abolishing posts that have become obsolete since the change in political systems. Anyone from west or east can apply for the jobs, which have been advertised widely.

A commission headed by the president and chancellor of the university makes the final decision on applicants. It also can point the finger at anyone judged to have abused their connections with the East German secret police - although such investigations are also being conducted by education ministers in each of Germany's 16 states (see Nature 359, 762; 1992). This means that incumbent staff will have to compete not only with western German scientists but also with their past.

This sudden - and very expensive change is part of a scheme to impose uniform standards on the employment of academic staff. Although the process may be harsh on the 1,800 staff at Humboldt, many academics are expected to keep their jobs. The university announced last week that 100 people, 44 from Humboldt and 56 from western Germany, have already been recruited for the 550 positions to be filled.

Matthew Beard 